San Jose State University

SJSU ScholarWorks

Mineta Transportation Institute Publications

$6-2021$

\title{
Robotic Parking Technology for Congestion Mitigation and Air Quality Control Around Park \& Rides
}

\author{
Mahdi Yoozbashizadeh \\ California State University, Long Beach \\ Forouzan Golshani \\ California State University, Long Beach
}

Follow this and additional works at: https://scholarworks.sjsu.edu/mti_publications

Part of the Transportation Commons, and the Transportation Engineering Commons

\begin{abstract}
Recommended Citation
Mahdi Yoozbashizadeh and Forouzan Golshani. "Robotic Parking Technology for Congestion Mitigation and Air Quality Control Around Park \& Rides" Mineta Transportation Institute Publications (2021). https://doi.org/10.31979/mti.2021.1936
\end{abstract}

This Report is brought to you for free and open access by SJSU ScholarWorks. It has been accepted for inclusion in Mineta Transportation Institute Publications by an authorized administrator of SJSU ScholarWorks. For more information, please contact scholarworks@sjsu.edu. 


\section{SJSU}

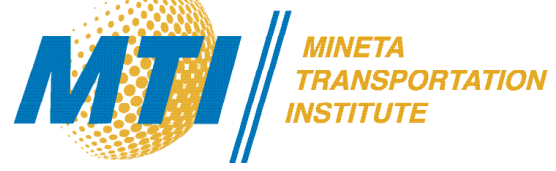

Robotic Parking Technology for Congestion Mitigation and Air

Quality Control Around Park \& Rides

Mahdi Yoozbashizadeh

Forouzan Golshani

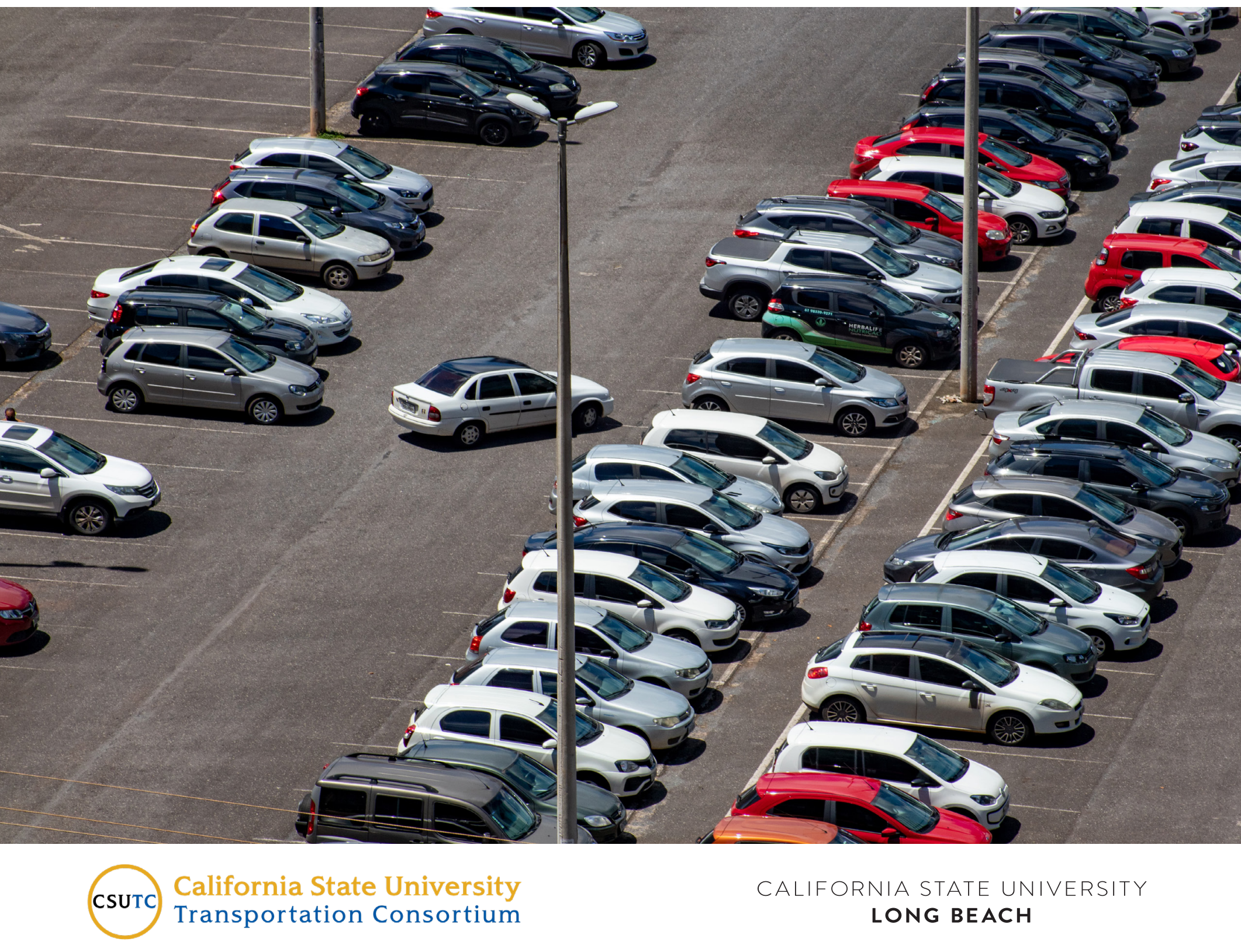




\section{Mineta Transportation Institute}

Founded in 1991, the Mineta Transportation Institute (MTI), an organized research and training unit in partnership with the Lucas College and Graduate School of Business at San José State University (SJSU), increases mobility for all by improving the safety, efficiency, accessibility, and convenience of our nation's transportation system. Through research, education, workforce development, and technology transfer, we help create a connected world. MTI leads the Mineta Consortium for Transportation Mobility (MCTM) funded by the U.S. Department of Transportation and the California State University Transportation Consortium (CSUTC) funded by the State of California through Senate Bill 1. MTI focuses on three primary responsibilities:

\section{Research}

MTI conducts multi-disciplinary research focused on surface transportation that contributes to effective decision making. Research areas include: active transportation; planning and policy; security and counterterrorism; sustainable transportation and land use; transit and passenger rail; transportation engineering; transportation finance; transportation technology; and workforce and labor. MTI research publications undergo expert peer review to ensure the quality of the research.

\section{Education and Workforce}

To ensure the efficient movement of people and products, we must prepare a new cohort of transportation professionals who are ready to lead a more diverse, inclusive, and equitable transportation industry. To help achieve this, MTI sponsors a suite of workforce development and education opportunities. The Institute supports educational programs offered by the Lucas Graduate School of Business: a
Master of Science in Transportation Management, plus graduate certificates that include High-Speed and Intercity Rail Management and Transportation Security Management. These flexible programs offer live online classes so that working transportation professionals can pursue an advanced degree regardless of their location.

\section{Information and Technology Transfer}

MTI utilizes a diverse array of dissemination methods and media to ensure research results reach those responsible for managing change. These methods include publication, seminars, workshops, websites, social media, webinars, and other technology transfer mechanisms. Additionally, MTI promotes the availability of completed research to professional organizations and works to integrate the research findings into the graduate education program. MTI's extensive collection of transportation-related publications is integrated into San José State University's world-class Martin Luther King, Jr. Library.

\section{Disclaimer}

The contents of this report reflect the views of the authors, who are responsible for the facts and accuracy of the information presented herein. This document is disseminated in the interest of information exchange. MTI's research is funded, partially or entirely, by grants from the California Department of Transportation, the California State University Office of the Chancellor, the U.S. Department of Homeland Security, and the U.S. Department of Transportation, who assume no liability for the contents or use thereof. This report does not constitute a standard specification, design standard, or regulation. 


\title{
Robotic Parking Technology for Congestion Mitigation and Air Quality Control around Park \& Rides
}

\author{
Mahdi Yoozbashizadeh \\ Forouzan Golshani
}

June 2021

\author{
A publication of the \\ Mineta Transportation Institute \\ Created by Congress in 1991 \\ College of Business \\ San José State University \\ San José, CA 95192-0219
}




\section{TECHNICAL REPORT DOCUMENTATION PAGE}

\begin{tabular}{|c|c|c|}
\hline $\begin{array}{c}\text { 1. Report No. } \\
21-18\end{array}$ & 2. Government Accession No. & 3. Recipient's Catalog No. \\
\hline \multirow{2}{*}{\multicolumn{2}{|c|}{$\begin{array}{l}\text { 4. Title and Subtitle } \\
\text { Robotic Parking Technology for Congestion Mitigation and Air } \\
\text { Quality Control around Park \& Rides }\end{array}$}} & $\begin{array}{l}\text { 5. Report Date } \\
\text { June } 2021\end{array}$ \\
\hline & & 6. Performing Organization Code \\
\hline \multicolumn{2}{|c|}{$\begin{array}{l}\text { 7. Authors } \\
\text { Mahdi Yoozbashizadeh } \\
\text { Forouzan Golshani }\end{array}$} & $\begin{array}{l}\text { 8. Performing Organization Report } \\
\text { CA-MTI-1936 }\end{array}$ \\
\hline \multirow{2}{*}{\multicolumn{2}{|c|}{$\begin{array}{l}\text { 9. Performing Organization Name and Address } \\
\text { Mineta Transportation Institute } \\
\text { College of Business } \\
\text { San José State University } \\
\text { San José, CA 95192-0219 }\end{array}$}} & 10. Work Unit No. \\
\hline & & $\begin{array}{c}\text { 11. Contract or Grant No. } \\
\text { ZSB12017-SJAUX }\end{array}$ \\
\hline \multirow{2}{*}{\multicolumn{2}{|c|}{$\begin{array}{l}\text { 12. Sponsoring Agency Name and Address } \\
\text { State of California SB1 2017/2018 } \\
\text { Trustees of the California State University } \\
\text { Sponsored Programs Administration } \\
\text { 401 Golden Shore, 5th Floor } \\
\text { Long Beach, CA } 90802\end{array}$}} & 13. Type of Report and Period Covered \\
\hline & & 14. Sponsoring Agency Code \\
\hline \multicolumn{3}{|c|}{$\begin{array}{l}\text { 15. Supplemental Notes } \\
10.31979 / \mathrm{mti} .2021 .1936\end{array}$} \\
\hline
\end{tabular}

\section{Abstract}

A lack or limited availability for parking may have multiple consequences, not the least of which is driver frustration, congestion, and air pollution. However, there is a greater problem that is not widely recognized by the public, namely the negative effect on the use of transit systems due to insufficient parking spaces close to key transit stations. Automated parking management systems, which have been successfully deployed in several European and Japanese cities, can manage parking needs at transit stations more effectively than other alternatives. Numerous studies have confirmed that quick and convenient automobile access to park-and-ride lots can be essential to making public transit competitive with the automobile in suburban areas.

Automated parking systems use a robotic platform that carries each vehicle to one of the locations in a custom designed structure. Each location is designed compactly so that considerably more vehicles can be parked in the automated garages than the traditional parking lots. Central to the design of these systems are three key technologies, namely:

1. Mechanical design and the operation of vehicle transfer, i.e., the robotic platform

2. Structural and architectural requirements to meet safety and earthquake standards, among other design imperatives,

3. Automation and intelligent control issues as related to the overall operation and system engineering.

This article concerns the first technology, and more specifically the design of the robotic platform for vehicle transfers. We will outline the overall design of the robot and the shuttle, followed by a description of the prototype that was developed in our laboratories. Subsequently, performance related issues and scalability of the current design will be analyzed.

\section{Key Words}

Park-and-ride, Parking facilities,

Multimodal transportation, Automated parking, Parking guidance systems

\section{Distribution Statement}

19. Security Classif. (of this report) 
Copyright (C) 2021

\section{by Mineta Transportation Institute}

All rights reserved.

DOI: $10.31979 / \mathrm{mti} .2021 .1936$

Mineta Transportation Institute College of Business San José State University San José, CA 95192-0219

Tel: (408) 924-7560

Fax: (408) 924-7565

Email: mineta-institute@sjsu.edu

transweb.sjsu.edu/research/1936 


\section{CONTENTS}





2. A Timely Alternative .......................................................................................... 2

3. Robotic Parking Structures ......................................................................... 4

4. A New Design for Lift and Transfer.......................................................... 6

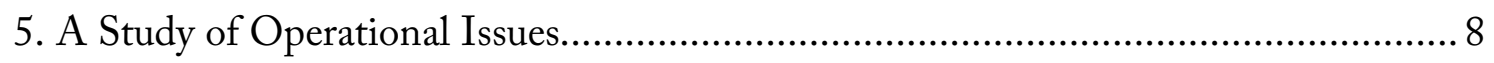

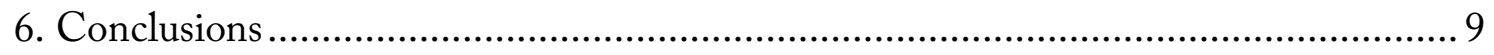

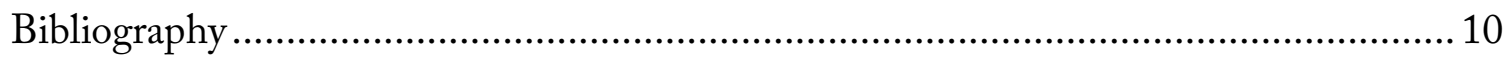

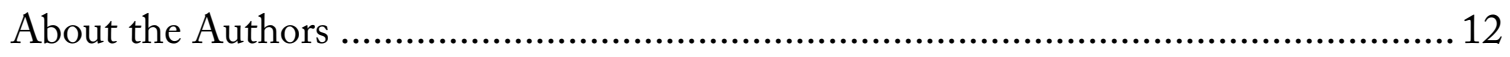




\section{LIST OF FIGURES}

Figure 1. The Two Main Variations of Structural Designs ............................................. 4

Figure 2. The First Robotic Platform, to be Used in Conjunction with Pallets ............. 6

Figure 3. An Enhanced Design for the Parking Platform - a Rover and



Figure 4. Final Fabricated Model for Full-Scale Testing ........................................... 7 


\section{Introduction}

It is imperative to not allow the challenge of parking inhibit the growth of public transportation. Recognizing the crucial role transit plays in the current economy and environment, automated parking facilities are great alternatives to traditional parking. Historically, automated parking systems have been very common and successful in Europe and Asia, particularly in highly populated areas. However, the USA has not been as enthusiastic about deploying this more sophisticated, but affordable solution.

Due to the large financial, environmental, and social advantages of robotic parking systems, one can expect that a robust and scalable design may be all that is needed to make this concept advantageous to a large number of cities and organizations in the U.S. The scarcity of available land in congested urban areas, coupled with the ever increasing real estate property values in congested areas, create a significant obstacle to addressing the substantial need for parking spaces close to Park \& Ride zones, thus making many of the potential development projects not feasible financially. As the cost of gasoline continues to climb, utilizing public transit systems becomes a much more attractive method of transportation for citizens. The availability of parking, specifically in congested areas, is a crucial step toward realizing the increased interest in transit ridership. A study conducted in San Francisco Bay Area concluded that, in addition to the regular users of transit system, there is a potential for increase of new riders, specifically those with relatively high incomes, high automobile availability, and variable work locations and schedules. [Rodier, 2010] Several other studies have confirmed the significant correlation that exists between transit use and the availability of parking at transit stations. See, for example, [Merriman, 1998, Ferguson, 2000] and another recent study by Inrix reporting that a typical Los Angeles driver spends an average of 85 hours looking for parking each year. [Inrix 2020]

With all the reasons noted above, developing an automated robust parking system, capable of transporting a vehicle from a designated spot to an available parking space, will overcome many of the persistent problems associated with parking in congested areas. 


\section{A Timely Alternative}

Recent technological advances suggest the possibility of a better parking experience, without the current aggravation and with the convenience of valet like service. Robotic parking systems can offer these and much more. Some of the major advantages of automated parking systems over traditional parking alternatives are:

- More efficient land use leading to an increased availability of parking spaces: In areas with current or high potential for transit ridership, increased availability of parking will attract more riders to take transit. Numerous field studies have indicated a significant increase in transit use when deploying a system that ensures availability of parking at destination facilities. [Rowe 2011]

- Return or increase in revenue to transit system: As increased parking is made available, transit systems are able to attract and serve larger numbers of riders. Because the space necessary for automated parking systems is smaller, valuable land is made available for potential development ventures, thus stimulating economic growth.

- Substantial reduction in operational costs to facility: Personnel required to maintain automated parking facilities are reduced significantly in the areas of security, dayto-day maintenance, and operations. Additional reductions are also achieved on long range costs such as the upkeep of lighting, concrete, and safety features. These are significant costs within the traditional parking garage and can be minimized or eliminated completely.

- Significant reduction in fuel consumption, carbon and nitrogen dioxide emissions: As the ignition is turned off at the point of entry to an automated parking facility, fuel consumption is eliminated since the vehicle is parked via automation. Obviously, it is not necessary to drive throughout the facility seeking a vacant parking space. Hence, the reduction in toxic gas emissions is achieved in the same fashion.

- Attractive economic potential for developers: Developers integrating automated parking into their plans may see a financial benefit through the attainment of LEED credits. (LEED - Leadership in Energy and Environmental Design - provides a framework for healthy, highly efficient, and cost-effective green buildings.) As stated before, high-tech solutions in the form of automated parking structures are the most efficient way to reduce the amount of physical space required for structured parking.

- $100 \%$ reduction in physical crime/assaults, car theft and damage to vehicles while parked: Statistics drawn from the Bureau of Justice report indicate that nearly $40 \%$ of theft attempts of either persons or automobiles resulting in personal injury occurred within parking facilities. Similarly, those statistics also report that around a quarter of successful automobile thefts occur within a parking facility. Access to automobiles by prospective vandals or car thieves is eliminated by the physical layout of an automated parking facility. The same principle applies to accidental minor incidents caused by other automobiles or pedestrians, thus leading to a reduction of auto insurance claims. 
It is not difficult to see that the potential gains of automated parking facilities are significant and multidimensional. Notably, robotic parking systems are more economical, safer, greener, and more secure than other methods of parking. The reference section addresses a large number of additional relevant studies that confirm this finding. 


\section{Robotic Parking Structures}

The overall design process incorporates three complementary perspectives including the structural and architectural requirements which must meet safety and earthquake standards, the mechanical design and operation of vehicle transfer, and intelligent control and automation which encompasses the overall operation and system engineering issues.

The structural design of the robotic parking garages can be divided into two broad categories of circular and square shaped designs:

Square-shaped structures: The robotic vehicle transfer system is different in square structures. The main components are one or more mechanical arms (akin to computerized lifts), pallets, and a shuttle system. The control system integrates the operations of the lifts, and the pallets and shuttle for placing and retrieving vehicles from parking bins in a multi-level garage. Once the vehicle is driven onto the pallet at the entrance, the lift moves the pallet with its cargo to the floor where an empty bin is available. The bin (i.e., a vacant parking spot) is chosen by the control system. Once on a pre-assigned floor, the pallet and the car are transported on the floor tracks by the shuttle to the designated bin. Once on the designated floor, the pallet and the car leave the lift and start moving, which are connected to every parking spot.
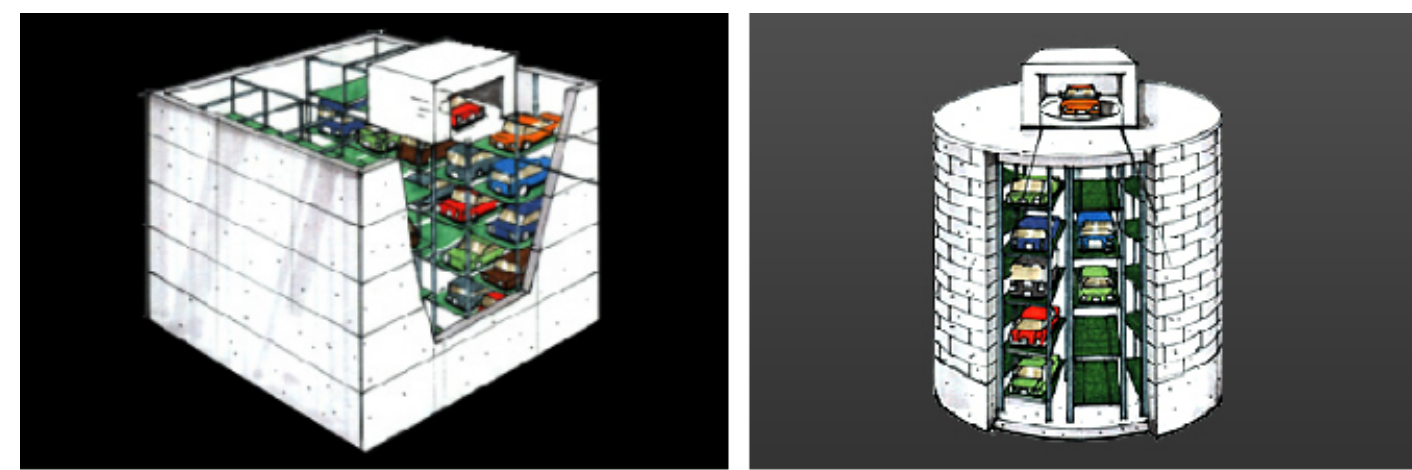

Square and Circular Shaped Parking Structures. Source: www.e-globalparking.com

Figure 1. The Two Main Variations of Structural Designs

Round structures: Making the best use of limited space, a cylindrical parking facility can achieve optimized use of space and a high degree of safety. One of the biggest advantages of a circular shaped design, specifically when built underground, is earthquake resiliency by virtue of a shock-absorbing structure that restrains tremors, regardless of the direction of the seismic wave. Compared to traditional multi-story garages of the same size, the amount of land space needed for a circular structure with the same number of floors is estimated to be about one third. The mechanical system for placement and retrieval of cars is simpler since the lift operates along the main shaft in the middle of the structure and the transfer into the bin does not require a separate shuttle. 
Regardless of the shape of the garage structure, the intelligent control system works the same. Once the vehicle is loaded onto the pallet at the entrance and all passengers have left the immediate area, the mechanical system lifts the vehicle and carries it to the parking space that is assigned by the control system. Considering the significant difference in size and weight of different cars (for example, a compact mini vs. a large Sports Utility Vehicle), a more sophisticated and more intelligent system can measure the dimensions of cars and weight of each car upon entry and assign the smallest available parking space to the vehicle.

It should be noted that many of the existing parking structures may be suited for retrofitting purposes, often referred to as Brownfield applications. A project is considered to be greenfield when it lacks constraints imposed by prior work on the site. Typically, such a project is deployed on a completely vacant site. By contrast, a brownfield project generally encounters constraints that are related to the current state of the site. Brown applications, which entail redeveloping a site, not only contribute to the economy by creating jobs and stimulating property values, but they improve the environmental conditions through improving health and safety factors. Generally redevelopment projects can be cheaper because of the availability of certain vital infrastructure, such as drainage, electricity and roads.

Whether repurposed or built anew, all safety and earthquake standards are applicable. Fortunately, in the case of robotic parking facilities, disaster situations are less likely to result in loss of life since there is no human traffic inside the automated parking garage.

While an end-to-end solution involves intricate details on architectural, structural, environmental, control and overall system design, the focus of this article is on the design of a mechanical system-called the rover - that can locate and transport a vehicle to a gantry and place it in a designated spot. Our design for this rover is unique in that it is a low cost/low maintenance machine which retains the efficiency and simplicity of other automated parking systems. 


\section{A New Design for Lift and Transfer}

The aim of this study is to develop a new robotic vehicle transfer system for square-shaped parking structures. Our team embarked on a multidisciplinary approach toward designing a more efficient, but affordable, robotic parking facility and fabricating a small scale prototype.

Two mechanical engineering senior capstone groups joined forces with the faculty team to design and fabricate multiple prototypes for the automated parking rover. The first prototype was constructed specifically to demonstrate that automated parking facilities do not necessarily require budgets in orders of millions of dollars. Even when manufactured by hand, the cost of this design was shown to be a fraction of the cost of the currently operating auto-parking robotic transports. Consisting of a pallet and shuttle, this method of transporting vehicles was new in the scope of automated parking. The following is an overview.

In this design, vehicles rest on pallets, isolated from the shuttle that transports them. This makes the design to be functional for virtually any street legal vehicle. The shuttle is designed with respect to the shape of the pallet, and as such no calibration is necessary for different types of vehicles. These features simplify automated parking such that it would be practical for general use. The team developed different experimental prototypes for this design. The fabricated prototype of the final design for the platform is presented in Figure 2 .

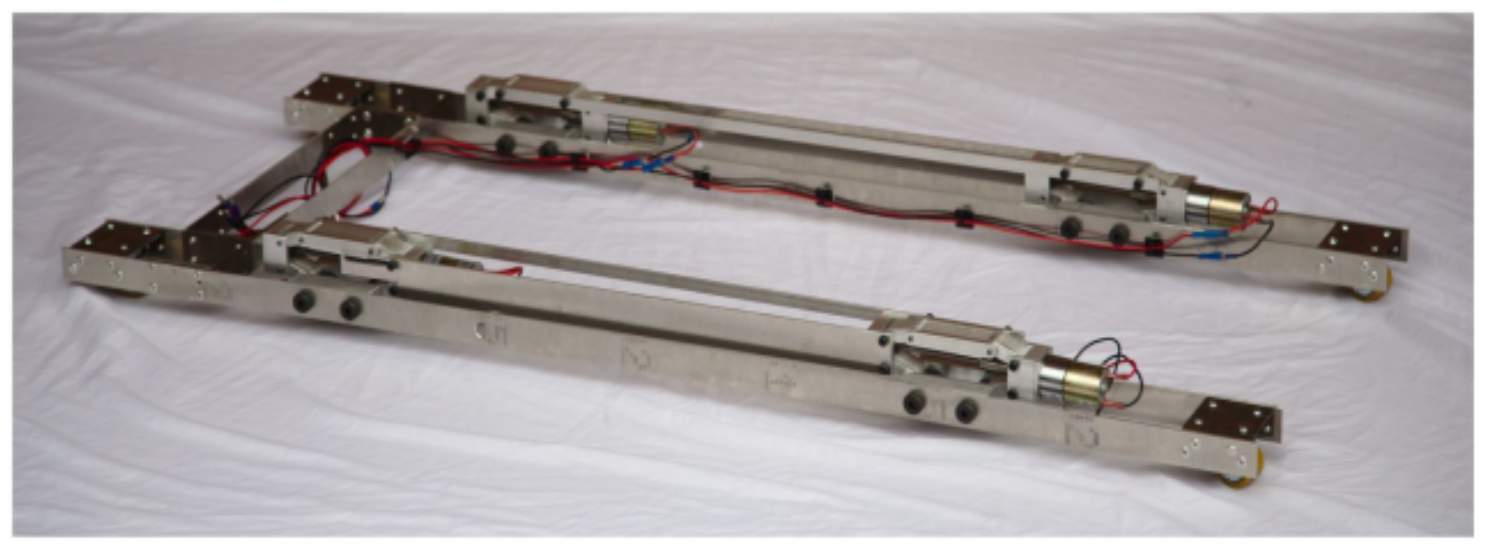

Figure 2. The First Robotic Platform, to be Used in Conjunction with Pallets

After testing and analyzing the first prototype, a more robust design was developed by the team. The second design was able to lift an object weighing one half of a large street vehicle. The underlying idea was for it to work in unison with another platform in order to lift the entire vehicle. The shuttle positions itself under the vehicle, and two retractable arms swing out making contact with the tires. The pinch force, applied to the tires, is able to lift the car off the ground, making it ready for transfer onto the gantry. The motion is produced through the use of heavy-duty line actuators. Figure 3 presents a side perspective of the 
rover and its arms. A complete prototype was fabricated at the CSULB College of Engineering laboratories for testing and verification purposes. The prototype is shown in Figure 4.



Figure 3. An Enhanced Design for the Parking Platform a Rover and its Mechanical Arms

The prototype was tested on a full-scale car (3,000 lbs of weight) and was able to lift the car and move it to in linear and circular motions. For the control of the linear actuators and rollers, a robust control algorithm was developed using color sensor and distance sensor as feedback. The system is capable to follow a line but an image processing will be added in the future to make it fully autonomous. The total cost of the current system is $\$ 5,000$ which is very economical to be used for green and brown applications.

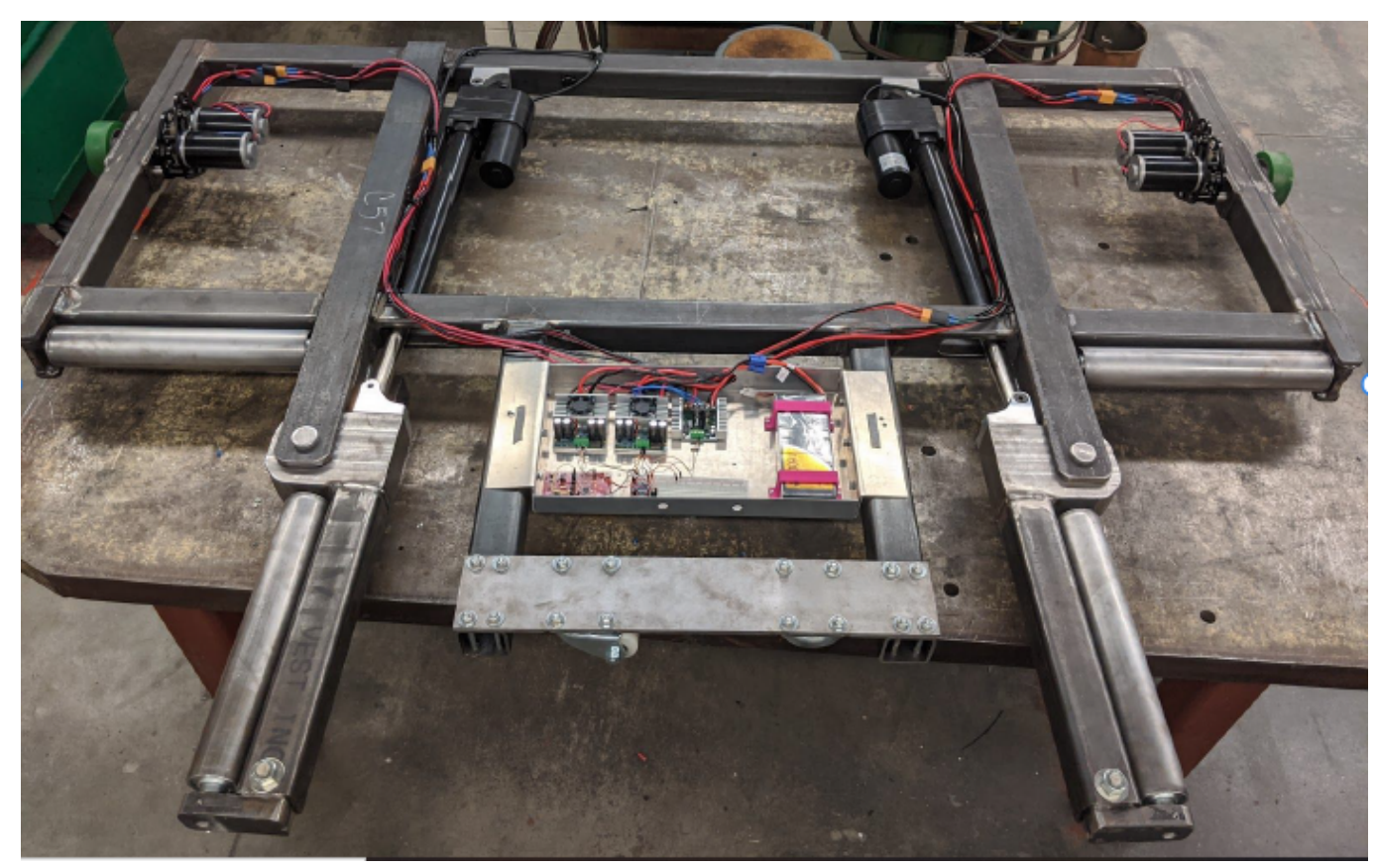

Figure 4. Final Fabricated Model for Full-Scale Testing 


\section{A Study of Operational Issues}

Besides costs and financial imperatives, two key parameters are highly important for the optimization and intelligent control of robotic parking. They are retrieval time (i.e., the wait time from when a vehicle is requested) and space utilization. For a comprehensive analysis, it is necessary to consider the overall shape of the structure, e.g., circular or rectangular, with the possibility of multiple floors and the availability of free pathways. We can apply queueing theory to estimate the waiting time, specifically for the circular structure, with the following parameters: average arrival rate, average departure rate, number of customers and number of robots. These parameters can be easily estimated using standard statistical techniques. For the rectangular structure, we can apply graph theory, queue theory, and multi-agent systems in order to obtain more specific analyses. The problem is modeled by a geometric graph, where the edges represent free paths and a set of $\mathrm{k}$ identical mobile robots are deployed on the graph. Two methods are available for simulating the robotic motion control. The first approach is centralized, where a central computer plans the routes for each robot, and the second is decentralized, where robots are able to selfcoordinate themselves while working collectively. In both cases, the routes must be conflict-free to guarantee the overall safety of the system. The centralized approach has the advantage of simplifying the design of the path planning algorithms when the number of robots is small. However, this method is not scalable since the computing complexity increases exponentially with the number of robots. The decentralized approach has the advantage of being scalable and more resilient. However, designing correct algorithms can be challenging and requires advanced techniques of distributed computing. 


\section{Conclusions}

The novel idea of this article is a newly designed, low-cost car lift and transfer platform for automated parking systems. This design is particularly attractive because it simplifies the operational aspects of vehicle placement and retrieval. The prototype for this design was fabricated very economically by a team of faculty and students.

Other relevant work conducted either in preparation or as a consequence of the proposed lift and transfer platform were: (a) simulated environments showing two different structures (one circular and one rectangular); modeled to house 300 cars; (b) documentation of a comprehensive literature study focusing on the overall design, the mechanical components, and the operation of automated parking structures; (c) a study of safety procedures and building requirements for automated parking structures; and (d) the development of a virtual model of automated parking structures for optimizing the pick-up and drop-off time. 


\section{Bibliography}

Automated Parking Corporation Team. "What Is the Cost of Automated Parking?" Automated Parking Corporation- Leaders in Automated Parking Systems, Automated Parking Corporation, www.apcpark.com/parking/what-is-the-cost-of-automatedparking/ Accessed September 10, 2019.

Bureau of Transportation Statistics (BTS). (February 2019). Number of U.S. Aircraft, Vehicles, Vessels, and Other Conveyances. https://www.bts.gov/content/number-usaircraft-vehicles-vessels-and-other-conveyances Accessed May 15, 2020.

Chun-Hao Tseng, et al. "Safety Evaluation for Campus Parking Garage Performance Using Fuzzy Logic." Journal of Performance of Constructed Facilities, Vol. 18, No. 3, Aug. 2004, pp. 127-135.

Chun-Hao Tseng, Neeraj, et al. "Performance of Campus Parking Garages in Preventing Crime.” Journal of Performance of Constructed Facilities, Vol. 18, No. 1, Feb. 2004, pp. 21-28.

Cao, Y., et al. "The Effect of Curb Parking on Road Capacity and Traffic Safety" European Transport Research Review, Vol. 9, No. 1, 2017, pp. 1-10.

Environmental Protection Agency (EPA), Fast Facts on Transportation Greenhouse Gas Emissions, June 2019, https://www.epa.gov/greenvehicles/fast-facts-transportationgreenhouse-gas-emissions Accessed May 15, 2020.

Environmental Protection Agency (EPA), March 2018, Greenhouse Gas Emissions from a Typical Passenger Vehicle. https://www.epa.gov/greenvehicles/greenhouse-gasemissions-typical-passenger-vehicle Accessed May 15, 2020.

Environmental Protection Agency (EPA), August 2016, EPA's Endangerment Finding. https://www.epa.gov/sites/production/files/2016-08/documents/endangermentfinding health.pdf Accessed May 15, 2020.

Environmental Protection Agency (EPA), 2016, Greenhouse Gases. https://www.epa.gov/report-environment/greenhouse-gases Accessed May 15, 2020.

Ferguson, E. Parking Management and Commuter Rail: The Case of Northeastern Illinois. Journal of Public Transportation, Vol. 3, No. 2, 2000, pp. 99-121.

Firgelli Automations Team. "Linear Actuators 101 - Everything You Need to Know about a Linear Actuator." Firgelli Automations, 16 Nov. 2018, www.firgelliauto.com/blogs/news/linear-actuators-101. 
Jaesung Han, and Kijung Park. "Development of a Pedestrian Safety Assessment Framework for Underground Parking Facilities and Its Application.” Journal of the Ergonomics Society of Korea, Vol. 38, No. 3, June 2019, pp. 203-218.

Inrix. "Searching for Parking Costs Americans $\$ 73$ Billion a Year." Inrix, www.inrix.com/press-releases/parking-pain-us/ Accessed April 27, 2020.

Merriman, D. How Many Parking Spaces Does It Take to Create One Additional Transit Passenger? Regional Science and Urban Economics, Vol. 28, 1998, pp. 565-584.

Rodier, C J., Shaheen, S A. Transit-Based Smart Parking: An Evaluation of the San Francisco Bay Area Field Test, April 2010, Transportation Research Part C Emerging Technologies 18(2):225-233, DOI: 10.1016/j.trc.2009.07.002 https://www.researchgate.net/publication/257429656 Transit-Based Smart Parking_An Evaluation of the San Francisco Bay Area Field Test

Rowe D H, Bae C, Shen Q., "Evaluating the Impact of Transit Service on Parking Demand and Requirements", Journal of Transportation Research Record, January 2011, https://doi.org/10.3141/2245-07 


\section{About the Authors}

\section{Mahdi Yoozbashizadeh}

Mahdi Yoozbashizadeh is an Associate Professor of Mechanical and Aerospace Engineering at CSU Long Beach. Previously he was a postdoctoral researcher at University of Southern California, where he completed a $\mathrm{PhD}$ program.

\section{Forouzan Golshani}

Forouzan Golshani is a Professor of Computer Science and Engineering and the former Dean of the CSULB College of Engineering. He is a Fellow of the National Academy of Inventors and IEEE. 
Founder, Honorable

Norman Mineta*

Secretary (ret.),

US Department of Transportation

Chair,

Abbas Mohaddes

President \& COO

Econolite Group Inc.

Vice Chair, Will

Kempton

Retired Transportation Executive

Executive Director,

Karen Philbrick, $\mathrm{PhD}^{*}$

Mineta Transportation Institute

San José State University

Winsome Bowen

Chief Regional Transportation

Strategy

Facebook

David Castagnetti Co-

Founder Mehlman

CastagnettiRosen \&

Thomas

\section{Maria Cino}

Vice President

America \& U.S. Government

Relations Hewlett-Packard

Enterprise

Grace Crunican**

Owner Crunican

LLC

Donna DeMartino

Managing Director

Los Angeles-San Diego-San Luis

Obispo Rail Corridor Agency
John Flaherty

Senior Fellow

Silicon Valley AmericanLeadership

Form

William Flynn *

President \& CEO

Amtrak

Rose Guilbault Board

Member Peninsula

CorridorJoint Powers

Board

Ian Jefferies*

President \& CEO

Association of American

Railroads

Diane Woodend Jones

Principal \& Chair of

BoardLea + Elliott, Inc.

David S. Kim*

Secretary

California State Transportation

Agency (CALSTA)

\section{Therese McMillan}

Executive Director Metropolitan

TransportationCommission (MTC)

Jeff Morales

Managing Principal InfraStrategies, LLC

Dan Moshavi, $\mathrm{PhD}$ *

Dean, Lucas College and Graduate

School of Business

San José State University
Toks Omishakin*

Director

California Department of

Transportation (Caltrans)

Takayoshi Oshima

Chairman \& CEO

Allied Telesis, Inc.

Greg Regan

President

Transportation Trades Department

Paul Skoutelas*

President \& CEO

American Public Transportation

Association (APTA)

Beverley Swaim-Staley

President

Union Station Redevelopment

Corporation

Jim Tymon*

Executive Director American Association of State Highway and Transportation Officials (AASHTO)

$*=$ Ex-Officio

** = Past Chair, Board of Trustees

\section{Directors}

Karen Philbrick, PhD

Executive Director

Hilary Nixon, PhD

Deputy Executive Director

Asha Weinstein Agrawal, PhD

Education Director

National Transportation Finance Center Director

Brian Michael Jenkins National Transportation Security Center Director

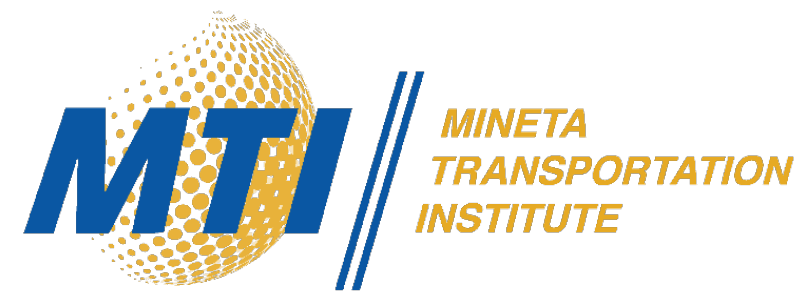

